\title{
Alternative splicing of parathyroid hormone-related protein mRNA: expression and stability
}

\author{
R S Sellers*, A I Luchin*, V Richard, R M Brena, D Lima and T J Rosol \\ Department of Veterinary Biosciences, The Ohio State University, 1925 Coffey Rd, Columbus, Ohio 43210, USA \\ (Requests for offprints should be addressed to Thomas J Rosol; Email: Rosol.1@osu.edu) \\ *(R S Sellers and A I Luchin contributed equally to this work)
}

\begin{abstract}
Parathyroid hormone-related protein (PTHrP) is a multifunctional protein that is often dysregulated in cancer. The human PTHrP gene is alternatively spliced into three isoforms, each with a unique $3^{\prime}$-untranslated region (3'-UTR), encoding 139, 173 and 141 amino acid proteins. The regulation of PTHrP mRNA isoform expression has not been completely elucidated, but it may be affected by transforming growth factor- $\beta 1$ (TGF- $\beta 1$ ). In this study, we examined differences in the PTHrP mRNA isoform expression in two squamous carcinoma cell lines (SCC2/88 and HARA), an immortalized keratinocyte cell line (HaCaT), and spontaneous human lung cancer with adjacent normal tissue. In addition, the effect of TGF- $\beta 1$ on PTHrP mRNA isoform expression and stability was examined. Cell-type specific expression of PTHrP mRNA isoforms occurred between the various cell lines, normal human lung, and immortalized human keratinocytes (HaCaT). PTHrP isoform expression pattern was significantly altered between normal lung tissue and the adjacent lung cancer. In vitro studies revealed that TGF- $\beta 1$ differentially altered the mRNA steady-state levels and mRNA stability of the PTHrP isoforms. Protein-RNA binding studies identified different proteins binding to the $3^{\prime}$-UTR of the PTHrP isoforms (139) and (141), which may be important in the differential mRNA stability and response to cytokines between the PTHrP isoforms. The data demonstrate that there is cell-type specific expression of PTHrP mRNA isoforms, and disruption of the normal regulation during cancer progression may in part be associated with TGF- $\beta 1$-induced changes in PTHrP mRNA isoform expression and stability.
\end{abstract}

Journal of Molecular Endocrinology (2004) 33, 227-241

\section{Introduction}

Parathyroid hormone-related protein $(\mathrm{PTHr})$ is a multifunctional protein that was initially identified as a tumor-secreted factor causing humoral hypercalcemia of malignancy (HHM) (Burtis et al. 1990, Dunne et al. 1993). The precise function of PTHrP in most adult tissues has not been completely elucidated, but has been reported to be important in growth and differentiation as well as cell proliferation and apoptosis (Wysolmerski \& Stewart 1998). PTHrP shares amino-terminal homology to parathyroid hormone $(\mathrm{PTH})$, and in patients with HHM, PTHrP is secreted into the circulation in a concentration sufficient to stimulate PTH/PTHrP receptors in kidney and bone causing increased serum calcium (Broadus \& Stewart 1994). Dysregulation of PTHrP gene expression in cancer has been attributed to be the cause for HHM, which has been reported in up to $20 \%$ of cancer patients (Rosol \& Capen 1992, Rankin et al. 1997, Sellers et al. 2000).

HHM has been most commonly reported in patients with carcinomas (Marino et al. 1993), and may be due to alterations in the cellular PTHrP isoform expression. The PTHrP gene is alternatively spliced at the $3^{\prime}$ end resulting in three isoforms encoding 139, 173 and 141 amino acid proteins, and different concentrations of PTHrP mRNA and their isoforms have been demonstrated in a tissue-specific manner (Southby et al. 1995, 1996, Philbrick et al. 1996). Only humans are known to express PTHrP 173. The PTHrP mRNA isoforms share the majority of the coding region, but differ in the $3^{\prime}$ end of the coding region and have different $3^{\prime}$-untranslated regions (3'-UTRs) 


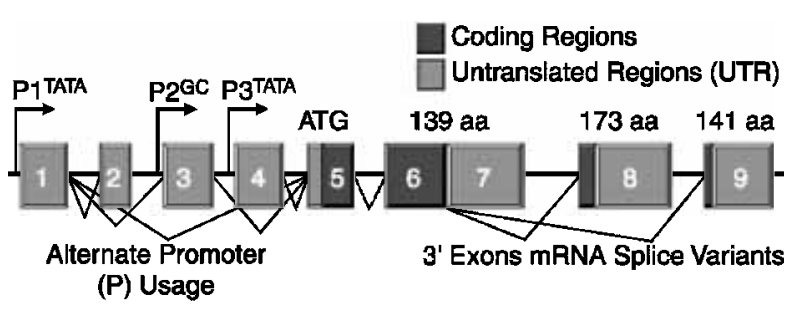

Figure 1 The PTHrP gene is differentially spliced into multiple isoforms. The PTHrP gene has three known alternative promoters (P1, P2 and P3) and nine exons. Exons 5 and 6 (coding exons) are alternatively spliced to exons 7,8 or 9 at the $3^{\prime}$ end into three mRNA variants to encode proteins of 139,173 and 141 amino acids.

(Fig. 1). The functional significance of the three 3'-UTR isoforms of PTHrP mRNA has not been established. Alternatively spliced PTHrP mRNAs may have products with differing functions and the regulation of these isoforms is likely to be tightly controlled.

It is known that the expression of PTHrP is induced by a number of signaling molecules, such as transforming growth factor- $\beta 1$ (TGF- $\beta 1$ ) and epidermal growth factor (EGF) (Heath et al. 1995, Werkmeister et al. 1998). In addition, the increased PTHrP mRNA expression associated with these cytokines has been demonstrated to be due, in part, to the stabilization of PTHrP mRNA (Heath et al. 1995, Benitez-Verguizas et al. 1999, Sellers et al. 2002). Studies have demonstrated that each of the PTHrP mRNA isoforms has a variable half-life that is differentially altered by cytokine treatment. For example, it has been reported that EGF increased the half-life of PTHrP 139 mRNA, but not PTHrP 141 or 173 mRNA (Heath et al. 1995). Although there are reports of the effect of TGF- $\beta 1$ on PTHrP mRNA transcription and stability (Heath et al. 1995, Benitez-Verguizas et al. 1999), regulation of PTHrP mRNA stability and steady-state levels of specific isoforms of PTHrP mRNA by TGF$\beta 1$ have not been extensively examined. In cancer, changes in the cellular PTHrP mRNA expression profile, through differences in the cytokine milieu or alterations in cell function, may contribute to the development of HHM or the rate of tumor metastasis (Guise et al. 2002).

In order to better understand the regulation of PTHrP mRNA expression and potential contributing factors for changes in expression patterns that might be important in cancer, we examined cell-type differences in PTHrP mRNA isoform expression in two carcinoma cell lines and an immortalized keratinocyte cell line, as well as pulmonary carcinoma and adjacent normal tissue. We further investigated the potential contribution of changes in PTHrP mRNA stability in the manifestation of these expression profiles. Specifically, we examined the effect of TGF- $\beta 1$, an important cytokine in cancer progression that increases PTHrP mRNA expression in epithelial cells, on the stability of the three PTHrP isoforms, and evaluated mRNA binding proteins that may play a role in PTHrP mRNA stability.

\section{Materials and methods}

\section{Cell lines and culture conditions}

Cell lines were originally isolated from a hypercalcemic human patient with a lung squamous carcinoma (HARA; generously donated by $\mathrm{H}$. Iguchi) (Iguchi et al. 1993, Takai et al. 1996, Nishigaki et al. 1999) and from a normocalcemic dog with an oral squamous carcinoma (SCC2/88) (Suter et al. 1991). The cell lines were chosen because both cell lines have been characterized to express and secrete PTHrP (Merryman et al. 1993, Takai et al. 1996, Nishigaki et al. 1999) as well as respond to TGF- $\beta 1$ to induce PTHrP mRNA (data not shown). SCC2/88 cells were cultured in William's E medium (Invitrogen, Carlesbad, CA, USA) with $2 \mathrm{mM}$ L-glutamine (Invitrogen), $50 \mu \mathrm{g} / \mathrm{ml}$ gentamicin, 10\% fetal calf serum (FCS; Invitrogen), $1 \mathrm{ng} / \mathrm{ml} \mathrm{EGF} \mathrm{(Invitrogen),} \mathrm{and} 10 \mu \mathrm{M}$ cholera toxin (Calbiochem, Inc., San Diego, CA, USA). HARA cells were cultured in RPMI with $10 \%$ FCS, $2 \mathrm{mM}$ L-glutamine, and $50 \mu \mathrm{g} / \mathrm{ml}$ gentamicin. At $60-80 \%$ confluence the cells were placed in basal medium (William's E or RPMI with $2 \mathrm{mM} \mathrm{L}$-glutamine and $50 \mu \mathrm{g} / \mathrm{ml}$ gentamicin) for 16-24 h prior to treatment with TGF- $\beta 1$.

\section{Patient samples}

The Division of Tissue Procurement at the James Cancer Hospital and Solove Research Institute at The Ohio State University provided human tissue samples. Adjacent neoplastic and normal samples were obtained from 15 human patients with a prior diagnosis of non-small cell lung carcinoma. The samples were obtained at surgery, snap frozen in 
liquid $\mathrm{N}_{2}$ and stored at $-80{ }^{\circ} \mathrm{C}$ until total RNA extraction. PTHrP expression was measured by quantitative RT-PCR (Richard et al. 2003). The four carcinomas with the greatest PTHrP expression were used for this study.

\section{Isolation and purification of total RNA}

Total RNA was used for the reverse transcription reaction to prepare templates for quantitative real-time PCR. Total RNA was extracted by either homogenization of 50-100 mg of frozen tissue with $1 \mathrm{ml}$ TRIzol reagent (Invitrogen) and a mortar and pestle or by homogenizing $5 \times 10^{6}$ cells in tissue culture plates. Chloroform $(0 \cdot 2 \mathrm{ml}$ chloroform per $1 \mathrm{ml}$ TRIzol) was added to homogenates and incubated at room temperature for 3-5 min and then centrifuged at 15000 r.p.m. for $15 \mathrm{~min}$ at $4{ }^{\circ} \mathrm{C}$. RNA, present in the aqueous phase, was precipitated with isopropanol by centrifugation at 15000 r.p.m. for $10 \mathrm{~min}$ at $4{ }^{\circ} \mathrm{C}$, and RNA pellets were washed with $70 \%$ RNase-free ethanol and re-precipitated by microcentrifugation. Total RNA was incubated twice for $30 \mathrm{~min}$ at $37^{\circ} \mathrm{C}$ with DNase I (10 U/ $\mu \mathrm{l}$; Roche, Indianapolis, IN, USA) in $10 \mathrm{mM}$ Tris $/ \mathrm{MgCl}_{2}$ buffer, followed by a second total RNA isolation using TRIzol reagent. The amount of RNA was measured spectrophotometrically by the absorbance at $260 \mathrm{~nm}$ and purity was determined by the ratio of the absorbance at 260/280 $\lambda\left(A_{260 / 280}\right)$. The RNA was stored in RNA storage solution (Ambion, Austin, TX, USA) at $-80^{\circ} \mathrm{C}$ until use. Dr J. Foley (Indiana University) generously provided total RNA extracted from HaCaT cells (immortalized human skin keratinocytes).

\section{Reverse transcription}

The reverse transcription (RT) reaction was used to prepare samples for quantitative real-time PCR. The RT reaction on cell line material was carried out in a total volume of $20 \mu \mathrm{l}$ of $1 \times \mathrm{RT}$ buffer containing $10 \mathrm{mM}$ dithiothreitol (DTT), $500 \mu \mathrm{M}$ deoxynucleotide triphosphates (dNTPs), $25 \mathrm{ng}$ oligo(dT) ${ }_{12-18}, 5 \mathrm{mM} \mathrm{MgCl}_{2}, 40 \mathrm{U}$ of RNase inhibitor, and $50 \mathrm{U}$ of Superscript II reverse transcriptase (Invitrogen). To this mixture, 2.5 $\mu \mathrm{g}$ of total RNA treated with DNase I was added. The reaction was allowed to proceed for $60 \mathrm{~min}$ at $42{ }^{\circ} \mathrm{C}$, followed by heating at $70{ }^{\circ} \mathrm{C}(5 \mathrm{~min})$ and rapid cooling on ice. Original total RNA was digested with $2 \mathrm{U}$ of $E$. coli RNase $\mathrm{H}$ for $20 \mathrm{~min}$ at $37^{\circ} \mathrm{C}$. Negative controls were prepared under the same conditions, but without addition of reverse transcriptase. RT reactions were performed in triplicate for each sample. RT reactions $(20 \mu \mathrm{l})$ were brought to a final volume of $50 \mu \mathrm{l}$ by adding RNase and DNase-free double-distilled water. The cDNA was stored at $-20{ }^{\circ} \mathrm{C}$ until use.

\section{Real-time quantitative PCR}

Utilizing cDNA from the previously described RT reaction, real-time quantitative PCR was used to measure the levels of expression of PTHrP mRNA isoforms and performed as previously described by our laboratory (Richard et al. 2003).

\section{Generation of PTHrP isoform-specific cDNA probes}

Isoform-specific cDNAs for PTHrP were used for detection of PTHrP mRNA in Northern blots and were generated by PCR. Primers were designed from exons 7, 8 and 9 to be specific to PTHrP 139, 173 and 141 respectively. The forward and reverse primers specific for PTHrP 139 (403 nt) were 5'-TTCTGCATTGGCTTGGACAA-3' and 5'CATGATGCTGTTGTGCAGTG-3'; for PTHrP 173 (447 nt) were 5'-CAGCACTTCTGTGGGG TTTG-3' and 5'-GGCAATAAAGTAGGGTCG TT-3'; and for PTHrP 141 (335 nt) were 5'-GGACATATTGCAGGATTCTG-3' and 5'CAACGACAAAATAGAGACAC-3'. PGR was conducted utilizing a Platinum Taq PGR amplification kit (Invitrogen) with $1 \times \mathrm{PCR}$ buffer, $2 \cdot 5 \mathrm{mM} \mathrm{MgCl}_{2}, 0 \cdot 2 \mathrm{mM} \mathrm{dNTPs}, 5^{\prime}$ and $3^{\prime}$ primers $(0 \cdot 2 \mu \mathrm{M})$, and $1 \mathrm{U}$ Platinum Taq polymerase (Invitrogen) at $95^{\circ} \mathrm{C}$ for $2 \mathrm{~min}$ followed by 35 cycles of 95,55 and $72{ }^{\circ} \mathrm{C}$ of 45 s each using a BioRad iCycler (BioRad Laboratories, Hercules, CA, USA). The PCR-amplified cDNA sizes were confirmed by electrophoresis using a $1.5 \%$ agarose gel and purified with the Qiaquick PCR purification kit (Qiagen, Valencia, CA, USA). ${ }^{32}$ P-labeled cDNA was generated using the StripEZ random primer cDNA labeling kit (Ambion) and the Qiaquick nucleotide removal kit (Qiagen) was used to remove unincorporated nucleotides.

\section{Northern blot analysis}

Northern blot analysis was used to measure PTHrP mRNA stability. Steady-state levels and stability of 
PTHrP mRNA stability were measured in carcinoma cells after treatment with $3 \mathrm{ng} / \mathrm{ml}$ TGF- $\beta 1$ (R \& D Systems, Minneapolis, MN, USA) or equal volume of vehicle $(0 \cdot 1 \%$ BSA in phosphatebuffered saline, PBS) for $6 \mathrm{~h}$. After $6 \mathrm{~h}$ of treatment with TGF- $\beta 1$ or vehicle, cells were treated with $25 \mu \mathrm{g} / \mathrm{ml}$ of the transcription inhibitor, 5,6dichloro-1-beta-ribofuranosyl benzimidazole (DRB, Calbiochem). At $0,1,2$ and $4 \mathrm{~h}$ after addition of DRB, total RNA was extracted from the cells with TRIzol reagent (Invitrogen) followed by chloroform extraction and ethanol precipitation as previously described. Total RNA $(20 \mu \mathrm{g})$ was separated on a $1 \%$ formaldehyde-agarose gel and transferred to a nylon membrane (Duralon, Invitrogen), crosslinked with u.v. light (Stratalinker, Stratagene, La Jolla, CA, USA), and hybridized with ${ }^{32}$ P-labeled cDNA for PTHrP exons 7, 8 or 9 (as previously described) and glyceraldehyde-3-phosphate dehydrogenase (GAPDH) (780 bp Pstl/Xbal fragment of human GAPDH) in Ultrahyb (Ambion) at $42{ }^{\circ} \mathrm{C}$ for $16 \mathrm{~h}$. Membranes were washed twice for 5 min at $42{ }^{\circ} \mathrm{C}$ in $2 \times \mathrm{SSC}$ and $0 \cdot 1 \%$ SDS and once for $30 \mathrm{~min}$ at $42{ }^{\circ} \mathrm{C}$ in $0 \cdot 1 \times \mathrm{SSC}$ and $0 \cdot 1 \% \mathrm{SDS}$. Blots were developed by autoradiography and quantitated using a PhosphorImager (425F-120, Molecular Dynamics, Sunnyvale, CA, USA).

\section{PTHrP immunoradiometric assay (IRMA)}

An IRMA (Diasorin, Stillwater, MN, USA) was used to measure concentration of secreted PTHrP (1-84) in culture medium. This assay measures PTHrP protein that is intact from amino acid 1-84 (termed PTHrP (1-84)), but cannot differentiate the individual isoforms. Each experiment was conducted three times in triplicate. Cells were treated with either TGF- $\beta 1(0 \cdot 1,1$ or $3 \mathrm{ng} / \mathrm{ml})$ or vehicle in 12-well plates. After $24 \mathrm{~h}$ of treatment, conditioned medium was collected and frozen at $-20{ }^{\circ} \mathrm{C}$ until analysis.

\section{DNA quantitation}

DNA from SCC2/88 cells was measured to normalize conditioned medium PTHrP concentrations between culture wells. After removal of the medium for the IRMA, cells were lysed with $5 \mathrm{M}$ guanidine isothiocyanate (GITG) containing 0.5\% sodium lauryl sarcosine and $20 \mathrm{mM}$ sodium citrate, and the lysate was stored at $-20^{\circ} \mathrm{C}$. DNA was measured using Hoescht 23345 dye (Sigma Biochem, St Louis, MO, USA) in a 96-well black U-bottom Microfluor plate (Dynatech Labs, Ashford, Middlesex, UK). Samples were aliquoted into $100 \mu \mathrm{l}$ TNE buffer $(10 \mathrm{mM}$ Tris $\mathrm{pH} 8 \cdot 0$, $0.5 \mathrm{mM}$ EDTA, $0.25 \mathrm{M} \mathrm{NaCl})$. The standard curve was generated with calf thymus DNA in TNE with an equivalent amount of GITC as used in the sample wells. 23345 Hoescht dye $(100 \mu \mathrm{l}$ of $0.1 \mathrm{mg} / \mathrm{ml}$ ) was added to each well and samples were measured at $450 \mathrm{~nm}$ on an IDEXX fluorometer (IDEXX, Westbrook, ME, USA).

\section{S100 cytoplasmic protein extraction}

S100 protein extracts were used in the u.v. cross-linking assay (see below), as previously described (Sellers et al. 2002). Briefly, cells were washed with ice-cold PBS, pelleted at $500 \boldsymbol{g}$ at $4{ }^{\circ} \mathrm{C}$, re-suspended in homogenization buffer (10 mM TRIS pH 7.4, $1.5 \mathrm{mM} \mathrm{MgCl}_{2}, 10 \mathrm{mM}$ $\mathrm{KCl}, 0.5 \mathrm{mM}$ DTT) with $1.5 \mathrm{mM} \mathrm{Na}$ orthovanadate (Sigma), $50 \mathrm{mM} \mathrm{NaF}$ (Sigma), $10 \mathrm{mg} / \mathrm{ml}$ pepstatin (Roche), $33 \mathrm{mg} / \mathrm{ml}$ aprotinin (Roche), and $0.3 \mathrm{mM}$ phenylmethanesulfonyl fluoride (PMSF, Sigma), and allowed to swell on ice for $20 \mathrm{~min}$. Samples were homogenized and nuclei were pelleted at $12000 \mathrm{~g}$ for $2 \mathrm{~min}$ at $4{ }^{\circ} \mathrm{C}$. Supernatants were transferred to an ultrafuge tube with 0.11 volumes of $10 \times$ extraction buffer (100 mM TRIS pH 7.4, $15 \mathrm{mM} \mathrm{MgCl}_{2}, 1.5 \mathrm{M}$ $\mathrm{KCl}, 5 \mathrm{mM}$ DTT) and centrifuged at $100000 \boldsymbol{g}$ at $4{ }^{\circ} \mathrm{C}$ for $1 \mathrm{~h}$ and the supernatant (S100) frozen in liquid nitrogen. Proteins were quantitated in triplicate utilizing the Bradford method (Brogdon \& Dickinson 1983).

\section{Generation of ${ }^{32} \mathrm{P}$-labeled PTHrP RNA in vitro}

${ }^{32}$ P-labeled PTHrP RNA fragments were used in the u.v. cross-linking assay. Regions of the 3 '-UTRs of PTHrP 139 and 141 mRNA isoforms were amplified by PCR using appropriate sets of primers (Table 1). All forward primers were tagged with a 5'-T7 promoter (TAATAGGACTCACTATAG GGA) for in vitro transcription, followed by the sequence of interest. PCR products were purified using the PCR Purification Kit (Qiagen).

The DNA templates were transcribed with the Maxi-Script kit (Ambion, Austin, TX, USA). Briefly, $1 \mu \mathrm{g}$ of template DNA was mixed with $1 \mu \mathrm{l}$ 
Table 1 DNA primers for PCR amplification of the 3'-UTR of PTHrP mRNA 139 and 141 for RNA-protein u.v. cross-linking

\author{
Primer \\ PTHrP 141 region 1 \\ Foward \\ Reverse \\ PTHrP 141 region 2 \\ Forward \\ Reverse \\ PTHrP 141 region 3 \\ Forward \\ Reverse \\ PTHrP 139 region 1 \\ Forward \\ Reverse \\ PTHrP 139 region 2 \\ Forward \\ Reverse \\ PTHrP 139 region 3 \\ Forward \\ Reverse \\ PTHrP 139 region 4 \\ Forward \\ Reverse
}

*T7 promoter: TAATACGACTCACTATAGGGA

of $100 \mathrm{mM}$ CTP, GTP and ATP, $2 \mu \mathrm{l} 10 \times$ transcription buffer, $3 \mathrm{ml}$ of $2 \mathrm{mM}$ UTP, $5 \mathrm{ml}$ of $3000 \mathrm{Ci}$ per mmol $\alpha-{ }^{32} \mathrm{P}-\mathrm{UTP}, 10 \mathrm{U}$ RNase inhibitor (Life Technologies), and 10 U T7 polymerase (Ambion). Samples were incubated at $37^{\circ} \mathrm{C}$ for $1 \mathrm{~h}$, heated to $95^{\circ} \mathrm{C}$ for $3 \mathrm{~min}$, and placed on ice. The DNA template was degraded with $2 \mathrm{U}$ of RNase-free DNase I (Ambion) at $37^{\circ} \mathrm{C}$ for $15 \mathrm{~min}$. RNA was extracted with acid phenolchloroform (Ambion), precipitated with isopropanol, and washed with $70 \%$ ethanol. The RNA was re-suspended in 20-50 $\mathrm{ml}$ diethyl pyrocarbonate (DEPC)-treated water (Sigma) and counted in a scintillation spectrophotometer.

\section{u.v. cross-linking assay}

An RNA-protein u.v. cross-linking assay was used to analyze the protein binding to the $3^{\prime}$-UTRs of PTHrP mRNA 139 and 141 (see Fig. 8) as previously described with minor modifications (Sellers et al. 2002). Briefly, S100 extracts (10 mg) were combined with 200000 c.p.m. of RNA with $\mathrm{BSA}(0.2 \mathrm{mg} / \mathrm{ml})$ (Amresco, Solon, OH, USA), $8 \mathrm{U}$ RNase inhibitor (Life Technologies), and $40 \mu \mathrm{g} / \mathrm{ml}$

\section{Sequences}

\author{
5'-T7*-GAGGCATTGAAATTTTCAGC-3' \\ 5'-TCACAATGACCAATGTGCAG-3' \\ 5'-T7-CTATGAAACTGCACATTGGTC-3' \\ 5'-TAGAGACACTTCATTGTGTC-3' \\ 5'-T7-GCACTTTAGATATACATATC-3' \\ 5'-GTAATTAGATTATATTTTATTAGAC-3' \\ 5'-T7-GATTCACGGTAACAGGCTTC-3' \\ 5'-GCAATTTATTGAATGTTTAC-3' \\ 5'-T7-ACTCTCACACCTGGGCAAAC-3' \\ 5'-TCCCTTGAAGTGAAAGAACG-3' \\ 5'-T7-ACTCTCACACCTGGGCAAAC-3' \\ 5'-AAACAAATTTAAGGCATGTG-3' \\ 5'-T7-TTATGTTTTAAACACATGCC-3' \\ 5'-TTTCTACGGCATTACCCTAG-3'
}

tRNA (Life Technologies), incubated on ice for $20 \mathrm{~min}$, and cross-linked with u.v. light $(0 \cdot 25 \mathrm{~J}$ total energy, $254 \mathrm{~nm}$ wavelength, $8 \mathrm{~cm}$ from source, Stratalinker, Stratagene) in $0.75 \mathrm{ml}$ Eppendorf tubes on ice. Samples were treated with $1 \mu \mathrm{g} / \mu \mathrm{l}$ RNase A (Sigma) at $37^{\circ} \mathrm{C}$ for $30 \mathrm{~min}$, mixed with loading buffer $(0.35 \mathrm{M}$ Tris-HCl $\mathrm{pH} 6 \cdot 8,30 \%$ (v/v) glycerol, 12\% (w/v) SDS, 0.6 M DTT, and $0.18 \mathrm{M}$ bromphenol blue), heated to $95^{\circ} \mathrm{C}$ for $3 \mathrm{~min}$, and separated using a 12\% SDS-PAGE gel with 37:1 acrylamide-bis-acrylamide (Ambion). The gel was run at $4{ }^{\circ} \mathrm{C}$ for $11 \mathrm{~h}$ at $30 \mathrm{~mA}$. Molecular weight standards were used to estimate the size of RNA-binding proteins (Rainbow Molecular Weight Markers, Amersham Pharmacia Biotech, Piscataway, NJ, USA).

\section{Statistics}

Data from the mRNA stability assays were analyzed using a single factor ANOVA analysis to determine the significance of differences between mean values. Probability $(P)$ values less than 0.05 were considered statistically significant. Graphical representation of data includes the means \pm S.E. 
A

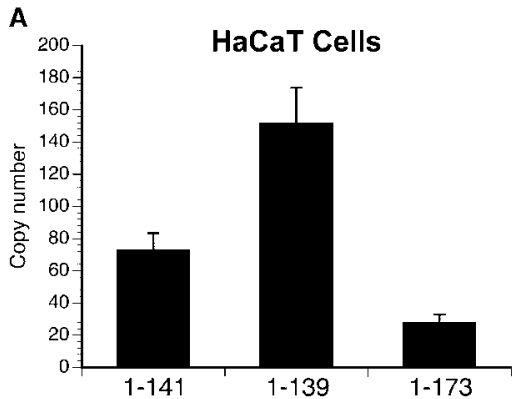

B

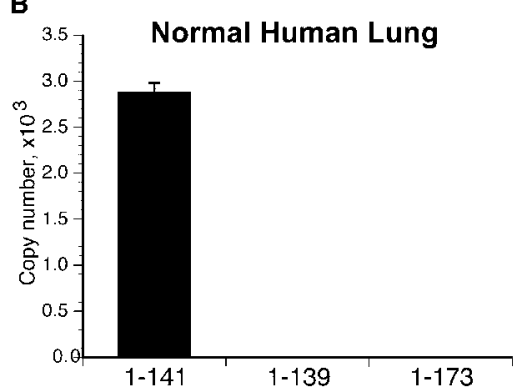

C

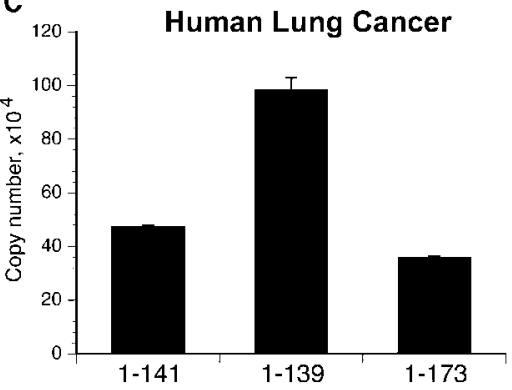

Figure 2 Tissue-specific expression of PTHrP mRNA isoforms in normal lung tissue and adjacent lung cancer and immortalized keratinocytes. Total RNA isolated from immortalized human keratinocytes (HaCaT cells), normal human lung tissue, and a non-small cell lung carcinoma with high PTHrP expression was reverse transcribed. Real-time quantitative PCR was used to measure the expression levels of PTHrP mRNA isoforms 139, 141 and 173. (A) The expression of the PTHrP $3^{\prime}$-isoforms in immortalized human keratinocytes included all three isoforms, with PTHrP 139 most highly expressed. (B) PTHrP 141 mRNA was the only isoform detected in normal lung tissue. (C) All three isoforms were detected in lung cancer tissue. Data represent normal lung tissue and associated lung tumor from a single patient, but similar results were obtained from all four patients examined. Values represent means \pm S.E.

Differences between PTHrP mRNA splice variants in each cell line were determined by one-way ANOVA and Bonferroni/Dunn multiple comparison test, and $P<0 \cdot 01$ values were considered significant. Comparison between lung carcinoma and normal samples was performed using the nonparametric Mann-Whitney $U$-test and Student $t$-test with $P<0.05$ (two-tailed) being significant. Statistical analysis was performed using Instat 3.01 (GraphPAD software).

\section{Results}

\section{Tissue-specific expression of PTHrP mRNA isoforms}

Alternative mRNA splicing is one way to achieve cell type and tissue-specific gene regulation. To precisely regulate $\mathrm{PTHrP}$ expression, different cells and tissues need the ability to activate PTHrP expression in response to certain signals such as TGF- $\beta 1$ or EGF in a differential manner. The production of the three different PTHrP isoforms by alternative splicing is one mechanism to achieve cell type and tissue-specific regulation, which may be altered during carcinogenesis or cancer progression. To test this hypothesis we measured the expression of the PTHrP 3'-isoforms in immortalized human keratinocytes (HaCaT cells) (Fig. 2A) and lung carcinoma and adjacent normal lung tissue from four patients undergoing tumor resection (Fig. 2B,C). Similar results were obtained from all four patients, and the representative results from one of the patients are presented in Fig. 2. We demonstrated that PTHrP 139 mRNA 
was the predominant isoform expressed in human keratinocytes, while PTHrP 141 mRNA was the only isoform detected in normal lung tissue (Fig. 2A,B). Interestingly, all three isoforms were detected in four lung cancers with high PTHrP mRNA expression (one example, Fig. 2C), demonstrating disruption of the normal regulation of PTHrP mRNA isoform expression during lung carcinogenesis.

\section{SCC2/88 and HARA cells have different concentrations of PTHrP isoforms}

In order to identify which isoforms of PTHrP were present in the two cell types and in what concentrations, we measured the steady-state levels of the PTHrP mRNA isoforms in SCG2/88 and HARA cells. We developed a quantitative real-time PGR approach to measure the relative levels of PTHrP mRNA. The 141 isoform was the predominant isoform expressed in SCG2/88 cells (Fig. 3A), with very little PTHrP 139 expression. As expected, no PTHrP 173 was identified in the SCC2/88 cells. In HARA cells, PTHrP 139 mRNA was the predominant isoform, which was 2.5-fold greater than PTHrP 141 mRNA expression and sevenfold greater than PTHrP 173 mRNA expression (Fig. 3B).

\section{PTHrP mRNA (all transcripts) stability increased by TGF- $\beta 1$ in SCC2/88 but not HARA cells}

Total PTHrP mRNA stability in the carcinoma cell lines (SCC2/88 and HARA) was measured after treatment with vehicle or TGF- $\beta 1$ for $6 \mathrm{~h}$, followed by treatment with the transcription inhibitor, DRB. Northern blot analysis using a cDNA probe to the coding region of PTHrP (common to all three isoforms) revealed that TGF- $\beta 1$ treatment significantly $(P<0 \cdot 02)$ increased the steady-state mRNA levels in SCG2/88 and HARA cells $(2 \cdot 5-$ and $1 \cdot 8$-fold respectively, Fig. $4 \mathrm{~A}$ and $\mathrm{C}$ based on time point 0 ). Northern blot analysis also revealed an average PTHrP mRNA half-life of $45 \mathrm{~min}$ in SCG2/88 cells (Fig. 4A,B) and 240 min in HARA cells (Fig. 4C,D) treated with vehicle. Comparison of $m R N A$ stability between TGF- $\beta 1$-treated SCC2/88 and vehicletreated cells demonstrated that PTHrP mRNA halflife increased from approximately 30 to $90 \mathrm{~min}$ $(P<0 \cdot 05)$ compared with vehicle treatment. TGF-

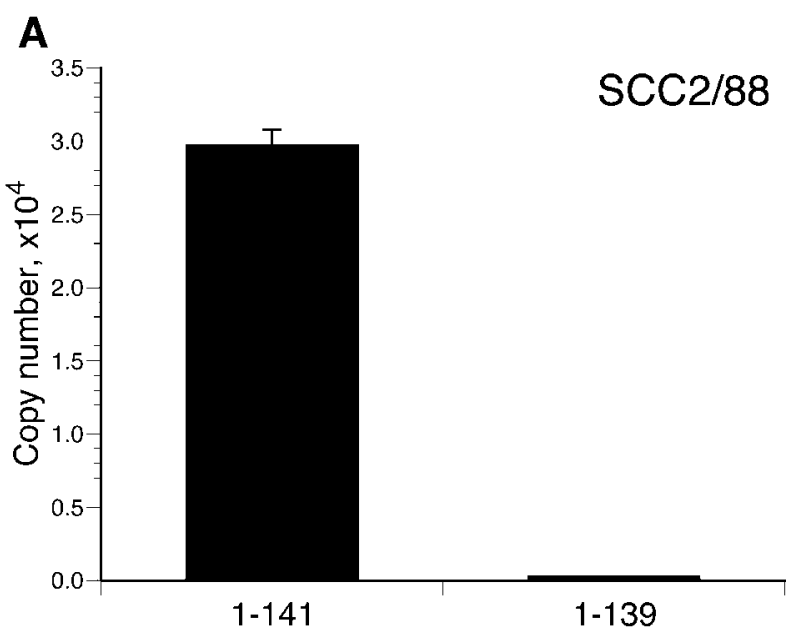

B

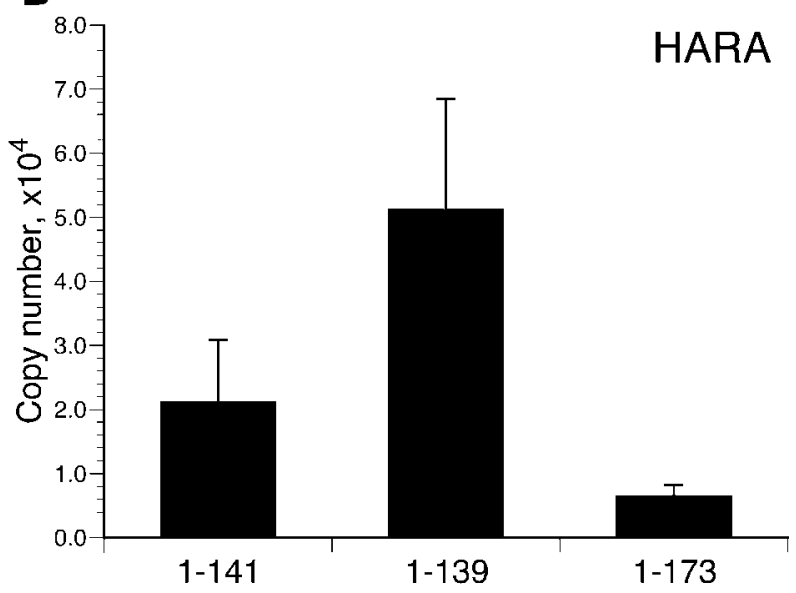

Figure 3 SCC2/88 and HARA cells have different concentrations of PTHrP isoforms. Total RNA was isolated from SCC2/88 and HARA cell cultures and reverse transcribed. Real-time quantitative PCR was used to measure the expression levels of PTHrP mRNA isoforms 139, 141 and 173. (A) SCC2/88 cells have high mRNA expression of PTHrP 141 and very little PTHrP 139. PTHrP mRNA isoform 173 does not exist in dogs. (B) HARA cells have high mRNA expression of PTHrP 139, less PTHrP 141, and little PTHrP 173. These results represent the means \pm S.E. of three experiments.

$\beta 1$ had no effect on PTHrP mRNA stability in HARA cells (Fig. 4G,D).

\section{PTHrP mRNA stability of isoform 141, but not 139 or 173 , was increased by TGF- $\beta 1$ in SCC2/88 and HARA cells}

Alternative splicing of the $3^{\prime}$ end of PTHrP gene results in three different isoforms of PTHrP mRNA 


\section{$\operatorname{SCC} 2 / 88$}

A
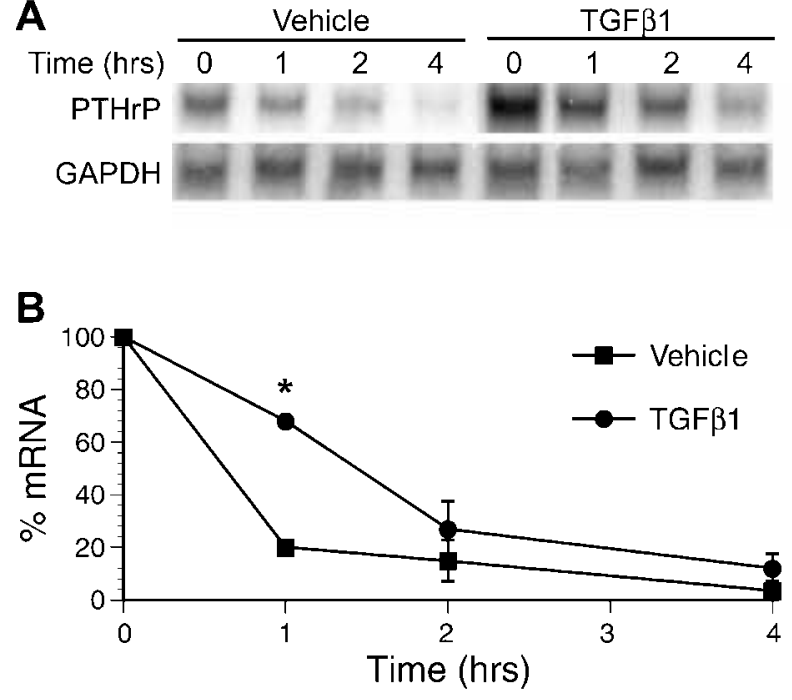
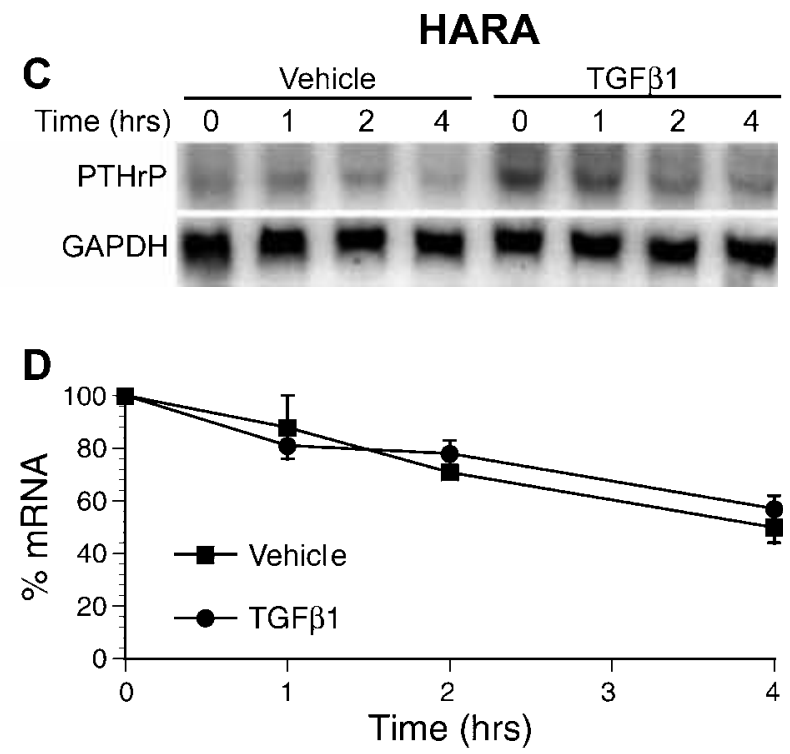

Figure 4 PTHrP mRNA stability (all transcripts) was increased in SCC2/88 cells but not HARA cells by TGF- $\beta 1$ $(3 \mathrm{ng} / \mathrm{ml})$. After $6 \mathrm{~h}$ of TGF- $\beta 1(3 \mathrm{ng} / \mathrm{ml})$ or vehicle treatment, $0.25 \mathrm{ng} / \mathrm{ml}$ of the transcription inhibitor, DRB, was added to SCC2/88 and HARA cell cultures and total RNA was extracted at $0,1,2$ and $4 \mathrm{~h}$. Twenty micrograms of total RNA was analyzed by Northern blot to measure all PTHrP mRNA transcripts (all isoforms) and the control mRNA, GAPDH. PTHrP data were normalized to GAPDH. (A) Northern blot of PTHrP mRNA expression in SCC2/88 cells. PTHrP expression was greater $6 \mathrm{~h}$ after TGF- $\beta 1$ treatment than controls (time 0 ). (B) Image analysis of all data (three experiments, means \pm S.E.) revealed that PTHrP mRNA half-life in SCC2/88 cells increased twofold after TGF- $\beta 1$ treatment. (C) Northern blot of PTHrP mRNA expression in HARA cells. (D) Image analysis of all data (three experiments, means \pm S.E.) revealed that PTHrP mRNA half-life was not altered by TGF- $\beta 1 .{ }^{*} P<0 \cdot 05$, significantly different from controls at same time point.

(139, 141, 173) (Broadus \& Stewart 1994). We investigated whether the differences in the effect of TGF- $\beta 1$ on total PTHrP mRNA stability between the SCC2/88 and HARA cells could be attributed to expression of different isoforms in $\mathrm{SCC} 2 / 88$ and HARA cells by measuring the effect of TGF- $\beta 1$ on the half-life of each of the PTHrP mRNA isoforms.

Northern blot analysis of HARA and SCG2/88 squamous carcinoma cells using specific cDNA probes for exons 7, 8 and 9 revealed differences in mRNA half-life between the various isoforms and differences in the effect of TGF- $\beta 1$ on mRNA half-life. The half-life of PTHrP mRNA with exon 9 (PTHrP 141) was 45 min in SCG2/88 cells (Fig. 5A,B) and $90 \mathrm{~min}$ in HARA cells (Fig. 5C,D). TGF- $\beta 1$ treatment increased the mRNA half-life of exon 9-containing transcripts (141) twofold in SCG2/88 cells $(P<0.05$ at $1 \mathrm{~h})$ and threefold in HARA cells $(P<0.05$ at 1 and $4 \mathrm{~h})$ (Fig. 5). The half-life of PTHrP mRNA transcripts containing exon 7 (PTHrP 139) in the canine SCC2/88 cells (Fig. 6A,B) and human HARA cells (Fig. 6C,D) was 90 and $120 \mathrm{~min}$ respectively. Treatment of both cell lines for $6 \mathrm{~h}$ with TGF- $\beta 1$ did not alter the mRNA stability of transcripts containing exon 7 (139 isoform) (Fig. 6), even though TGF- $\beta 1$ mildly increased steady-state mRNA expression of PTHrP $1391 \cdot 5$ - and 1.7-fold $(P<0 \cdot 05)$ compared with vehicle treatment in SCC2/88 and HARA cells respectively. The half-life of mRNA containing exon 8 in HARA cells (PTHrP 173, not present in dogs) was more than $4 \mathrm{~h}$ and did not significantly increase after TGF- $\beta 1$ treatment (Fig. 7A,B). Since this isoform is constitutively stable, it is possible that the 173 isoform is used when the constitutive expression of PTHrP is necessary. Thus, PTHrP $141 \mathrm{mRNA}$ was the only isoform in which mRNA stability was affected by TGF- $\beta 1$.

\section{Secretion of PTHrP (1-84) into conditioned medium after treatment with TGF- $\beta 1$}

We analyzed the secretion of PTHrP protein (1-84) by SCG2/88 cells in response to TGF- $\beta 1$ stimulation. Conditioned medium from 24-h cultures of cells treated with $0,0 \cdot 3,1 \cdot 0$ or 

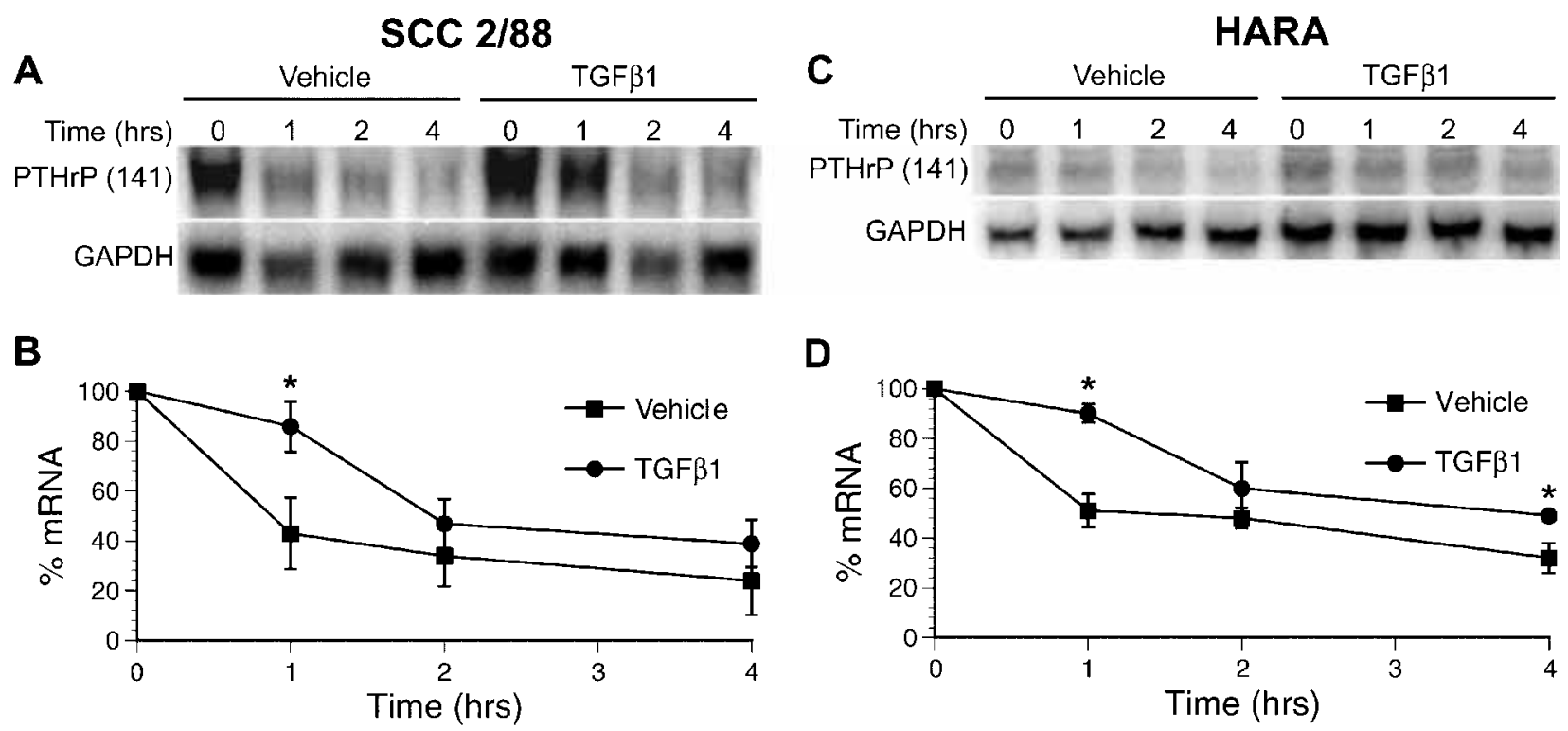

Figure 5 PTHrP (141) mRNA stability was increased in HARA or SCC2/88 cells by TGF- $\beta 1$ ( $3 \mathrm{ng} / \mathrm{ml})$. After $6 \mathrm{~h}$ of TGF- $\beta 1(3 \mathrm{ng} / \mathrm{ml})$ or vehicle treatment, $0.25 \mathrm{ng} / \mathrm{ml}$ of the transcription inhibitor, DRB, was added to SCC2/88 and HARA cell cultures and total RNA was extracted at $0,1,2$ and $4 \mathrm{~h}$. Twenty micrograms of total RNA was analyzed by Northern blot to measure PTHrP mRNA isoform 141 and the control mRNA, GAPDH. PTHrP data were normalized to GAPDH. (A) Northern blot of PTHrP $141 \mathrm{mRNA}$ expression in SCC2/88 cells. (B) Image analysis of all data (three experiments, means \pm S.E.) revealed that PTHrP mRNA half-life in SCC2/88 cells increased twofold after TGF- $\beta 1$ treatment. (C) Northern blot of PTHrP 141 mRNA expression in HARA cells. (D) Image analysis of all data (three experiments, means \pm S.E.) revealed that PTHrP mRNA half-life was increased threefold by TGF- $\beta 1$. ${ }^{*} P<0.05$, significantly different from controls at same time point.

$3 \cdot 0 \mathrm{ng} / \mathrm{ml}$ TGF- $\beta 1$ demonstrated significant differences between baseline and TGF- $\beta 1$-induced PTHrP concentrations in SCC2/88 cells. All values were normalized to total DNA. The conditioned medium of SCC2/88 cells had $7 \cdot 5 \pm 1 \cdot 2 \mathrm{pM}$ $\mathrm{PTHrP} / \mu \mathrm{g}$ DNA. TGF- $\beta 1(0 \cdot 3,1 \cdot 0$ and $3 \cdot 0 \mathrm{ng} / \mathrm{ml})$ significantly increased PTHrP in the conditioned medium of SCC2/88 cells at all concentrations $(P \leq 0 \cdot 01): 24 \pm 7 \cdot 0,29 \pm 6 \cdot 2$, and $35 \pm 3 \cdot 2$ PTHrP $\mathrm{pM} / \mu \mathrm{g}$ DNA respectively. Conditioned medium from HARA cells had concentrations of PTHrP below detectability of the assay.

\section{Differences and similarities in proteins binding to the $3^{\prime}$-UTRs of PTHrP 141 and 139 mRNA isoforms}

As we demonstrated, the 173 isoform of PTHrP mRNA was very stable (half-life $>4 \mathrm{~h}$ ), as compared with the 139 and 141 isoforms. Regulation of mRNA turnover (stability) may be more effective in the two isoforms with relatively short half-lives. The stability of the PTHrP 141 mRNA isoform, but not the 139 isoform, was increased by TGF- $\beta 1$. Interestingly, it has been reported that the stability of the 139 mRNA isoform, but not 141, was increased by EGF (Heath et al. 1995). PTHrP 141 and 139 mRNA isoforms have nearly identical coding regions (two amino acid difference), but quite different $3^{\prime}$-UTRs. The stability of mRNA is often regulated by trans-acting factors binding to the 3'-UTR of mRNA (Chen et al. 1994). Since the $3^{\prime}$-UTR is the only region of PTHrP mRNA that differs between PTHrP 141 and 139, we hypothesized that the differential effects of TGF- $\beta 1$ and EGF on PTHrP 141 and 139 mRNA isoform expression were determined by the difference in trans-acting factors that bind to the $3^{\prime}$-UTRs. Therefore, the PTHrP 141 and 139 3'-UTRs were expected to display different patterns of RNAbinding proteins.

We performed the u.v. cross-linking assay to analyze the proteins that bind to the $3^{\prime}$-UTRs of the 139 and 141 isoforms of PTHrP mRNA. The PTHrP 139 and 141 3'-UTRs were divided into four and three regions, respectively (Fig. 8A), 

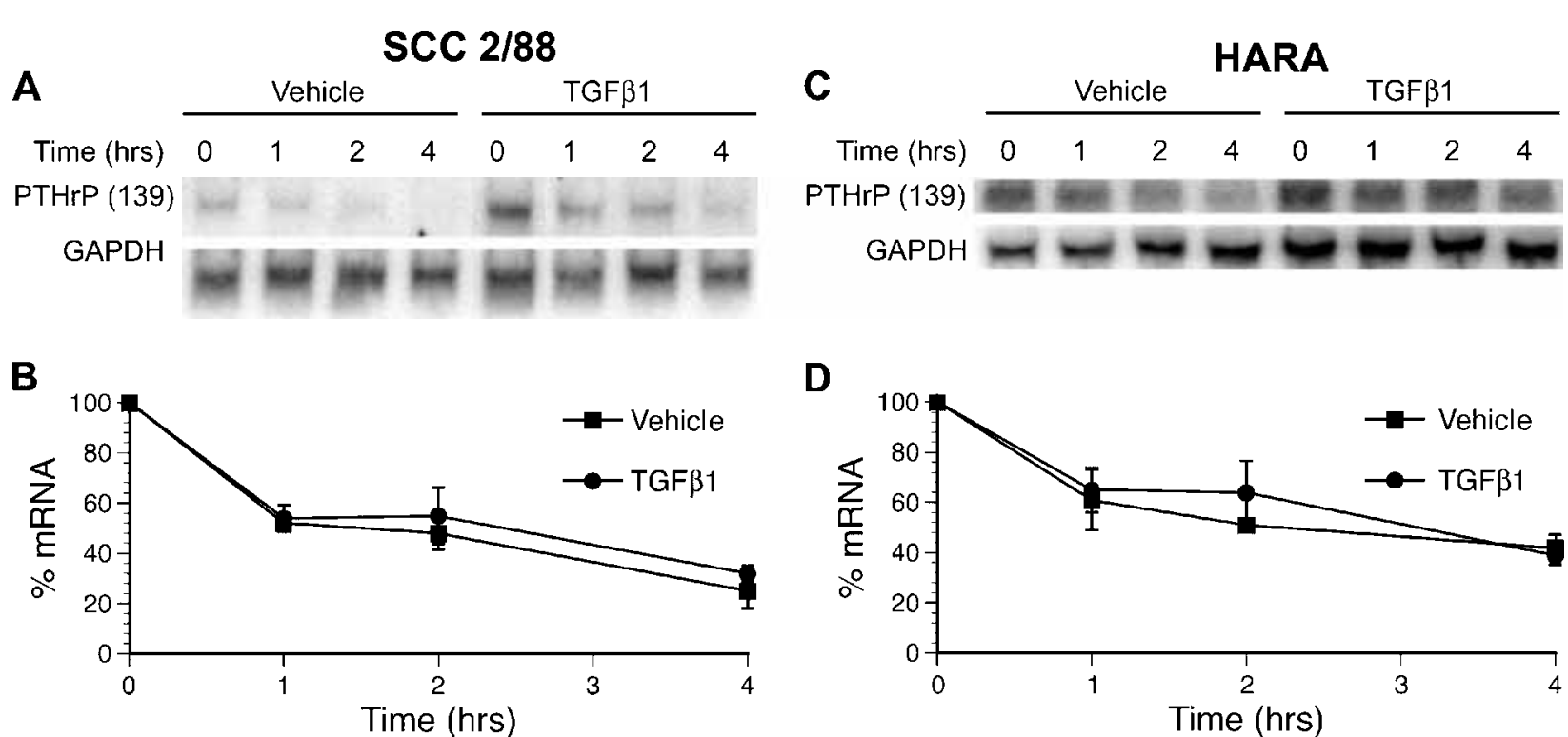

Figure 6 PTHrP (139) mRNA stability was not increased in SCC2/88 or HARA cells by TGF- $\beta 1$ (3 ng/ml). After 6 h of TGF- $\beta 1$ ( $3 \mathrm{ng} / \mathrm{ml})$ or vehicle treatment, $0.25 \mathrm{ng} / \mathrm{ml}$ of the transcription inhibitor, DRB, was added to SCC2/88 and HARA cell cultures and total RNA was extracted at 0, 1, 2 and $4 \mathrm{~h}$. Twenty micrograms of total RNA was analyzed by Northern blot to measure PTHrP mRNA isoform 139 and the control mRNA, GAPDH. PTHrP data were normalized to GAPDH. (A) Northern blot of PTHrP 139 mRNA expression in SCC2/88 cells. Expression of PTHrP 139 mRNA was 1.5 -fold greater after $6 \mathrm{~h}$ of TGF- $\beta 1$ treatment as compared with controls (time 0$)$. (B) Image analysis of all data (three experiments, means \pm S.E.) revealed that PTHrP mRNA half-life in SCC2/88 cells was not altered after TGF- $\beta 1$. (C) Northern blot of PTHrP 139 mRNA expression in HARA cells. Expression of PTHrP 139 mRNA was 1.7 -fold greater after $6 \mathrm{~h}$ of TGF- $\beta 1$ treatment as compared with controls (time 0 ). (D) Image analysis representative of all data (three experiments, means \pm S.E.) revealed that PTHrP mRNA half-life was not altered by TGF- $\beta 1$ treatment.

and the in vitro transcribed RNAs were crosslinked to the HARA S100 cytoplasmic extracts. Indeed, we observed different patterns of proteins that were cross-linked to the PTHrP 139 and 141 mRNA isoforms (Fig. 8B). The predominant protein bound to the 141 3'-UTR had the mobility of approximately $64 \mathrm{kDa}$ (region 3), while the predominant protein that bound to the PTHrP 139 3'-UTR (region 2) had a mobility of approximately $55 \mathrm{kDa}$. Two other proteins with the mobility of approximately 80 and $100 \mathrm{kDa}$ bound to PTHrP 141 3'-UTR, but not to 139 3'-UTR, while a protein with a mobility of approximately $45 \mathrm{kDa}$ cross-linked to the PTHrP 139 3'-UTR, but not to the 141 3'-UTR. Both PTHrP mRNA 3'-UTRs for the 139 and 141 isoforms have binding proteins in the range of $37-40 \mathrm{kDa}$. Thus, the trans-acting factors bound to the $3^{\prime}$-UTRs of the two PTHrP mRNA isoforms may contribute to both the rapid turnover of the 139 and 141 PTHrP mRNA isoforms and to the differential response of these isoforms to TGF- $\beta 1$ and other growth factors (e.g. EGF).

\section{Discussion}

Alternative splicing of the $3^{\prime}$ region of the PTHrP gene results in three different mRNA isoforms, encoding proteins of 139, 173 and 141 amino acids (Fig. 1). These isoforms share the majority of the coding region, and the 141 and 139 protein isoforms are identical except for the addition of two amino acids at the $\mathrm{C}$-terminus of the 141 isoform. Alternative splicing of the three isoforms, however, results in unique $3^{\prime}$-UTRs with some similar motifs (Broadus \& Stewart 1994). The physiological importance of the alternative splicing of PTHrP remains unknown.

Alternative splicing is an important mechanism in the regulation of gene expression. Alternative mRNA splicing increases the coding capacity of 

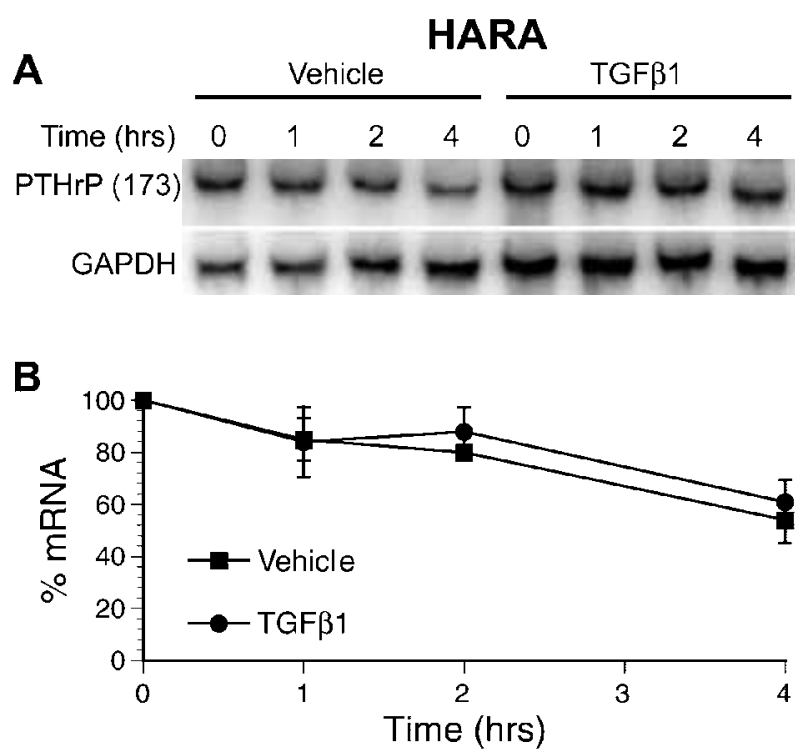

Figure 7 PTHrP (173) mRNA stability was not increased in HARA cells by TGF- $\beta 1(3 \mathrm{ng} / \mathrm{ml})$. After $6 \mathrm{~h}$ of TGF- $\beta 1(3 \mathrm{ng} / \mathrm{ml})$ or vehicle treatment, $0.25 \mathrm{ng} / \mathrm{ml}$ of the transcription inhibitor, DRB, was added to HARA cell cultures and total RNA was extracted at $0,1,2$ and $4 \mathrm{~h}$. Twenty micrograms of total RNA was analyzed by Northern blot to measure PTHrP mRNA isoform 173 and the control mRNA, GAPDH. PTHrP data were normalized to GAPDH. (A) Northern blot of PTHrP 173 mRNA expression in HARA cells. (B) Image analysis of all data (three experiments, means $\pm S$.E.) revealed that PTHrP mRNA half-life was not altered by TGF- $\beta 1$ treatment.

genes and enhances protein diversity (Smith \& Valcarcel 2000, Caceres \& Kornblihtt 2002). Numerous examples exist of alternative splicing of genes resulting in proteins with different or opposing functions. For example, alternative splicing of the calcitonin gene, important in calcium homeostasis, results in the expression of both calcitonin and calcitonin gene-related protein (CGRP), which have different functions and are expressed in a tissue-specific manner (Lou \& Gagel 1998, 1999). Additionally, alternative splicing may result in mRNA variants with different half-lives, as in the case of PTHrP. For example, alternatively spliced insulin-like growth factor-I transcripts within the growth plate have differential mRNA stabilities that have been interpreted to be important in the regulation of chondrocyte growth (Laugero \& Oberbauer 2000). It is likely that alternative splicing of PTHrP mRNA is important
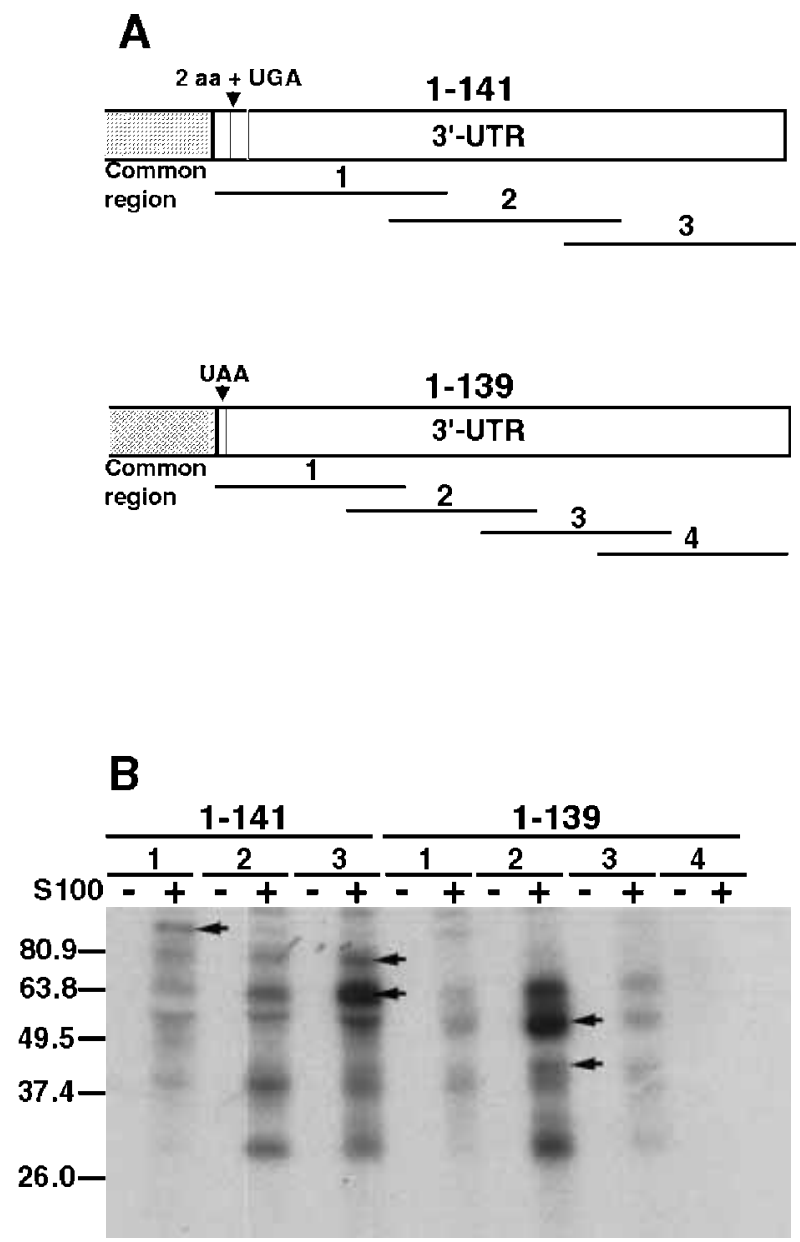

Figure 8 Different proteins bind to the $3^{\prime}$-UTRs of PTHrP 141 and 139 mRNA isoforms. (A) PTHrP 139 and $1413^{\prime}$-UTRs were divided into four and three regions respectively, and the in vitro transcribed RNAs were cross-linked to HARA S100 cytoplasmic extracts. (B) A different pattern of proteins (arrows) was cross-linked to PTHrP 139 mRNA as compared with the $141 \mathrm{mRNA}$ isoform. The predominant protein bound to the PTHrP 141 3'-UTR had the mobility of approximately $64 \mathrm{kDa}$ (region 3 ), while the predominant protein that bound to the PTHrP $1393^{\prime}$-UTR (region 2) had a mobility of approximately $55 \mathrm{kDa}$. Negative (-) lanes have RNA but no protein, positive $(+)$ lanes contain both S100 extract and RNA.

for the normal paracrine and intracrine function of PTHrP in specific cell types.

Human tissues express one or more of the alternatively spliced PTHrP mRNA isoforms (Mangin et al. 1988, Southby et al. 1995, Philbrick et al. 1996, Wysolmerski \& Stewart 1998), and tissue-specific expression has been described. Indeed, we and others have demonstrated that 
human HaCaT keratinocytes and human lung tissue express different PTHrP mRNA isoforms with the 139 isoform being predominant in $\mathrm{HaCaT}$ cells, and the 141 isoform being the only isoform detected in normal lung tissue (Heath et al. 1995, Southby et al. 1995). Evidence of altered regulation of PTHrP mRNA in cancer cells was demonstrated in human lung cancer, which expressed all PTHrP mRNA isoforms in a pattern more similar to transformed keratinocytes (HaCaT) and HARA cells than the normal adjacent lung tissue, which expressed only the PTHrP 141 mRNA isoform. Lung cancers often express higher levels of TGF- $\beta 1$ mRNA (Colasante et al. 1997), which may contribute to changes in PTHrP isoform expression between normal and cancerous tissue. Additional studies on the effect of TGF- $\beta 1$ on PTHrP mRNA isoform expression in lung tissue are ongoing in our laboratory. Changes in the isoform expression in certain cancers have been suggested to have important implications for disease prognosis. For example, increased expression of PTHrP mRNA (139) may correlate to increased risk of bone metastasis in breast cancer (Bouizar et al. 1999, Guise et al. 2002). It is likely that alterations in isoform expression also contribute to the development of HHM. Further comparisons of tumor PTHrP isoform expression and both tumor progression and the development of HHM are important for understanding the role of PTHrP in both normal and neoplastic conditions.

The mechanism by which changes in isoform expression occur in cancer has not been elucidated. However, the regulation of PTHrP mRNA expression has been demonstrated to be modulated by many factors, including TGF- $\beta 1$, EGF, angiotensin II, estrogen, and colchicine (Gillespie et al. 1992, Merryman et al. 1994, Heath et al. 1995, Groene et al. 1998, Werkmeister et al. 1998). These factors frequently alter PTHrP mRNA expression at the transcriptional level, through the use of alternative promoters, potentially with contributions from tissue-specific transcription factors. However, these factors may also regulate PTHrP gene expression post-transcriptionally through alternative splicing and changes in mRNA turnover (Mitchell \& Tollervey 2000).

In our studies, we demonstrated that TGF- $\beta 1$, a cytokine frequently increased in tumors and important in cancer progression (Gold 1999, Wakefield \& Roberts 2003), increases the mRNA stability of PTHrP 141, but not the other two isoforms. Previous studies have reported that the half-life of PTHrP mRNA (all transcripts) ranges from $30 \mathrm{~min}$ to more than $3 \mathrm{~h}$, depending on the cell type (Heath et al. 1995, Werkmeister et al. 1998, Benitez-Verguizas et al. 1999). Based on our studies, it is likely that the wide range of PTHrP mRNA half-lives (all transcripts) reported in the literature was due to differences in isoform expression. This finding also explains why the stability of total PTHrP mRNA in HARA cells was not increased by TGF- $\beta 1$. HARA cells expressed predominately the PTHrP 139 mRNA isoform, which was not stabilized by treatment with TGF- $\beta 1$. In mRNA stability assays using the probe for all transcripts of PTHrP mRNA, the stabilizing effect of TGF- $\beta 1$ on PTHrP 141 isoform in HARA cells was likely masked by the high mRNA expression of PTHrP 139 and the presence of the long-lived 173 mRNA isoform in these cells, both of which were not stabilized by TGF- $\beta 1$. In contrast, the stability of PTHrP mRNA (all transcripts) increased in SCG2/88 cells, which predominately expressed the PTHrP mRNA 141 isoform (the isoform that was stabilized by TGF- $\beta 1$ ). Because PTHrP mRNA transcripts containing exon 8 (PTHrP 173) are more stable than the other two transcripts, variations in the expression level of transcripts containing exon 8 (PTHrP 173) may account for the marked differences in PTHrP mRNA stability in various cell lines. Expression of PTHrP 173 mRNA isoforms may be important in the pathogenesis of HHM in humans, and further studies on isoform expression in association with HHM would be important in elucidating the mechanism of this paraneoplastic syndrome. Among domestic animals, dogs are reported to develop HHM more frequently than other species, but analysis of the specific PTHrP mRNA/protein isoform expressed has not been examined (Anderson et al. 1999, Kubota et al. 2002). It is known that dogs can express both the PTHrP 139 and 141 isoforms, but not the 173 isoform (Groene et al. 2002). Cats frequently develop squamous cell carcinomas and lymphomas yet rarely develop HHM as compared with dogs and humans (Bollinger et al. 2002). Cats also express both the 139 and 141 PTHrP isoforms (Tannehill-Gregg et al. 2001) and not PTHrP 173, similar to dogs. Differences between species in the development of HHM may represent differences in transcriptional 
responses as well as variations in mRNA stability. Further examination of PTHrP isoform expression in various species with HHM will be necessary to understand the comparative pathogenesis of cancer-associated hypercalcemia.

Studies examining the effect of EGF on PTHrP mRNA stability demonstrated stabilization of PTHrP mRNA containing exons 7 (PTHrP 139), but not 9 (PTHrP 141), in human immortalized keratinocytes (HaCaT) (Heath et al. 1995). This is in contrast to effect of TGF- $\beta 1$ on PTHrP mRNA isoform stability described in this study. It is probable that both TGF- $\beta 1$ and EGF increase PTHrP mRNA stability, but the mechanisms for this increase likely differ between the two growth factors. The mechanisms by which TGF- $\beta 1$ and EGF increase PTHrP mRNA stability remain uncertain. Numerous studies have demonstrated a significant role of the $3^{\prime}$-UTR in regulating mRNA turnover (Chen et al. 1994, Chen \& Shyu 1995, Mitchell \& Tollervey 2000). With this in mind we examined the differences between the proteins binding the 3'-UTRs of PTHrP 139 and 141, both of which have relatively short half-lives. These two isoforms have virtually identical coding region sequences with very different 3 '-UTR sequences. Previous studies in our lab have demonstrated reduced binding of some proteins to the terminal coding region of the PTHrP 141 mRNA isoform with TGF- $\beta 1$ treatment (Sellers et al. 2002). These studies, however, did not identify proteins that differentially bound to the 3'-UTR of PTHrP 141 mRNA after TGF- $\beta 1$ treatment. The molecular weight of the $3^{\prime}$-UTR binding proteins found previously were the same as described in this study. With these previous data, we examined the differences between the proteins binding the 3'-UTRs of PTHrP 139 and 141. The goal of these experiments was to examine differences in the binding proteins in the $3^{\prime}$-UTRs between the PTHrP 141 and 139 isoforms. We hypothesized that the short mRNA half-life of these two isoforms may be due to similar $3^{\prime}$-UTR-binding proteins, and the difference in the stabilizing effect of TGF- $\beta 1$ and EGF on the PTHrP 141 and 139 isoforms may be due to differences in the $3^{\prime}$-UTR binding proteins. Our mRNA-protein u.v. crosslinking experiments confirmed that there were distinct differences in protein binding to the 3'-UTR of these mRNA isoforms, in addition to proteins with similar size.
Numerous 3'-UTR-binding proteins associated with mRNA degradation have been described, and include AUF-1 family members, tristetetraprolin (TTP), K homology-type splicing regulatory protein (KSRP), hnRNPA1, hnRNPG, and AU-A, AU-B, AU-C (Bevilacqua et al. 2003). While our previous studies did not find an effect of TGF- $\beta 1$ on protein binding in the $3^{\prime}$-UTR, the short half-life of the PTHrP mRNAs may be mediated by proteins binding the $3^{\prime}$-UTR that promote rapid degradation. Both PTHrP mRNA 3'-UTRs for the 139 and 141 isoforms have binding proteins in the range of $37-40 \mathrm{kDa}$, which is consistent with the molecular weight of $\mathrm{p} 37^{\mathrm{AUF}-1}$ and $\mathrm{p} 40^{\mathrm{AUF}-1}$ isoforms, both of which promote mRNA degradation (Wilson et al. 2001). Proteins binding to the PTHrP 141 3'-UTR had the mobility of approximately 64, 80 and $100 \mathrm{kDa}$. Proteins binding to the PTHrP 139 3'-UTR had a mobility of approximately 45 and $55 \mathrm{kDa}$. Of the unique differences in binding proteins found between the mRNA 3 '-UTRs, the $80 \mathrm{kDa}$ binding protein in the 3 '-UTR of PTHrP 141 is similar to the molecular weight of KSRP (reported to be $75 \mathrm{kDa}$ ), which has been suggested to recruit the exosome for mRNA degradation (Chen et al. 2001). We cannot rule out that the higher molecular weight bands may represent protein aggregates that may have been cross-linked together during the u.v. cross-linking portion of the experiments. We are currently pursuing the identification of these proteins, which may help elucidate the signaling pathways resulting in stabilization of PTHrP mRNA by TGF- $\beta 1$.

Our data also demonstrated that in addition to increasing PTHrP mRNA expression in carcinoma cell lines, TGF- $\beta 1$ also increased PTHrP protein secretion into the conditioned medium in SCG2/88 cells. The concentration of PTHrP in the conditioned medium of HARA cells was at the low end of assay detection, and as such, the effects of TGF- $\beta 1$ on PTHrP secretion by these cells could not be evaluated. The two-site IRMA used to measure PTHrP in conditioned medium is very sensitive, but identifies only intact (1-84) peptides. Thus, the IRMA would not detect any calciotropic cleavage products (e.g. 1-36) in the medium. This may explain the discrepancy between the mRNA expression and the IRMA results. Both HARA and SCG2/88 cells had similar PTHrP mRNA expression levels, but only SCC2/88 cells had substantial PTHrP protein in the conditioned 
medium by the IRMA. It is possible that PTHrP secreted by HARA cells was cleaved before or after secretion and therefore was not detectable by the IRMA. Immunohistochemical data on these cell lines (data not shown) demonstrated significant intracellular protein expression in both cell lines. Alternatively, PTHrP has been demonstrated to have intracrine effects, which may result in intracellular-specific actions of PTHrP without secretion. Ultimately, studies on the relationship between increases in PTHrP mRNA isoform expression and stability by TGF- $\beta 1$ or other modulators, and protein expression, cleavage and secretion will be essential to fully understand the actions of these isoforms in both normal and neoplastic tissues and in the development of HHM.

The complexity of regulation of PTHrP mRNA splicing, post-translational control, and secretion make understanding the mechanisms of HHM and the role of PTHrP in normal physiology and cancer challenging. It is therefore important to take into consideration not only PTHrP mRNA isoform variation (including variations in the $5^{\prime}$-UTR), but also post-translational modifications and intracrine functions of PTHrP. Our results provide insight into the physiological significance of the alternative splicing of the $3^{\prime}$ end of the PTHrP gene and regulation of PTHrP mRNA stability by TGF- $\beta 1$. Information on the regulation of PTHrP mRNA isoform expression and mRNA stability will be important not only to understand its role in processes such as cancer, but also its role in development and cell differentiation. Further studies on PTHrP mRNA isoforms may be important for identifying predictors in cancer on the development of HHM, cancer invasion and metastasis, and response to medical intervention.

\section{Acknowledgements}

This work was supported by the National Institutes of Health, National Cancer Institute CA79110-01 (RSS) and CA77911, CA100730 (TJR) and the National Genter for Research Resources (RR00168) (TJR). Sincere thanks to Tim Vojt for his graphical expertise.

\section{References}

Anderson GM, Lane I, Fischer J \& Lopez A 1999 Hypercalcemia and parathyroid hormone-related protein in a dog with undifferentiated nasal carcinoma. Canadian Veterinary fournal 40 341-342.

Benitez-Verguizas J, Loarte D, de F \& Esbrit P 1999 Effects of transforming growth factor betal on cell growth and parathyroid hormone-related protein in Walker 256 tumor cells. Life Sciences 65 1807-1816.

Bevilacqua A, Geriani M, Capaccioli S \& Nicolin A 2003 Post-transcriptional regulation of gene expression by degradation of messenger RNAs. Fournal of Cellular Physiology 195 356-372.

Bollinger AP, Graham P A, Richard V, Rosol TJ, Nachreiner RF \& Refsal KR, 2002 Detection of parathyroid hormone-related protein in cats with humoral hypercalcemia of malignancy. Veterinary Clinical Pathology 31 3-8.

Bouizar Z, Spyratos F \& de Vernejoul MC 1999 The parathyroid hormone-related protein (PTHrP) gene: use of downstream TATA promoter and PTHrP 139 coding pathways in primary breast cancers vary with the occurrence of bone metastasis. Fournal of Bone and Mineral Research 14 406-414.

Broadus AE \& Stewart AF 1994 Parathyroid hormone-related protein: structure, processing, and physiological actions. In The Parathyroids, pp. 259-294. Eds JP Bilezikian, R Marcus \& MA Levine. New York: Raven Press.

Brogdon WG \& Dickinson CM 1983 A microassay system for measuring esterase activity and protein concentration in small samples and in high-pressure liquid chromatography eluate fractions. Analytical Biochemistry 131 499-503.

Burtis WJ, Brady TG, Orloff JJ, Ersbak JB, Warrell RP Jr, Olson BR, Wu TL, Mitnick ME, Broadus AE \& Stewart AF 1990 Immunochemical characterization of circulating parathyroid hormone-related protein in patients with humoral hypercalcemia of malignancy. New England Fournal of Medicine 322 1106-1112.

Caceres JF \& Kornblihtt AR 2002 Alternative splicing: multiple control mechanisms and involvement in human disease. Trends in Genetics 18 186-193.

Chen CY \& Shyu AB 1995 AU-rich elements: characterization and importance in mRNA degradation. Trends in Biochemical Sciences $\mathbf{2 0}$ 465-470.

Chen CY, Chen TM \& Shyu AB 1994 Interplay of two functionally and structurally distinct domains of the c-fos AU-rich element specifies its mRNA-destabilizing function. Molecular and Cellular Biology 14 416-426.

Chen CY, Gherzi R, Ong SE, Chan EL, Raijmakers R, Pruijn GJM, Stoecklin G, Moroni C, Mann M \& Karin M 2001 AU binding proteins recruit the exosome to degrade ARE-containing mRNAs. Cell $\mathbf{1 0 7} 451-464$.

Colasante A, Mascetra N, Brunetti M, Lattanzio G, Diodoro M, Caltagirone S, Musiani P \& Aiello FB 1997 Transforming growth factor $\beta 1$, interleukin-8 and interleukin-1, in non-small-cell lung tumors. American Fournal of Respiratory and Critical Care Medicine $\mathbf{1 5 6}$ 968-973.

Dunne FP, Lee S, Ratcliffe WA, Hutchesson AC, Bundred NJ \& Heath DA 1993 Parathyroid hormone-related protein (PTHrP) gene expression in solid tumours associated with normocalcaemia and hypercalcaemia. Fournal of Pathology 171 215-221.

Gillespie MT, Kiriyama T, Glatz JA, Suva LJ, Fukumoto S, Heath JK, Moseley JM, Rodan GA \& Martin TJ 1992 Response sequences for estrogen, EGF, and TGF $\beta$ in the human PTHrP gene overlap with sites for either NF-1 or SP-1. Bone and Mineral 17 (Suppl 1) 70.

Gold LI 1999 The role for transforming growth factor-beta (TGF- $\beta$ ) in human cancer. Critical Reviews in Oncogenesis 10 303-360.

Groene A, Weckmann MT, Capen CC \& Rosol TJ 1998 Regulation of parathyroid hormone-related protein expression in a canine squamous carcinoma cell line by colchicine. Experimental and Toxicologic Pathology 50 365-370.

Groene A, Weckmann MT, Rosol TJ 2002 Cloning and sequencing of the 3'-region of the canine PTHrP gene and analysis of 
alternate mRNA splicing in two canine carcinomas. Domestic Animal Endocrinology 22 169-177.

Guise TA, Yin JJ, Thomas RJ, Dallas M, Cui Y \& Gillespie MT 2002 Parathyroid hormone-related protein (PTHrP)-(139) isoform is efficiently secreted in vitro and enhances breast cancer metastasis to bone in vivo. Bone $\mathbf{3 0} 670-676$.

Heath JK, Southby J, Fukumoto S, O'Keefe LM, Martin TJ \& Gillespie MT 1995 Epidermal growth factor-stimulated parathyroid hormone-related protein expression involves increased gene transcription and mRNA stability. Biochemical foumal $\mathbf{3 0 7}$ 159-167.

Iguchi H, Katakami H, Ichinose Y, Nishi Y, Tanaka S, Hara N, Ohta M, Haji M \& Nawata H 1993 A case of squamous cell lung carcinoma with high concentration of parathyroid hormone-related peptide in serum and pleural effusion presenting hypercalcemia. Fapanese Fournal of Cancer Research 84 419-424.

Kubota A, Kano R, Mizuno T, Hisasue M, Moore PF, Watari T, Tsujimoto H \& Hasegawa A 2002 Parathyroid hormone-related protein $(\mathrm{PTHrP})$ produced by dog lymphoma cells. Fournal of Veterinary Medical Science 64 835-837.

Laugero LA \& Oberbauer AM 2000 Stability of alternatively spliced IGF-I mRNA in growth plate chondrocytes. Connective Tissue Research 41 165-174.

Lou H \& Gagel RF 1998 Alternative RNA processing - its role in regulating expression of calcitonin/calcitonin gene-related peptide. Journal of Endocrinology 156 401-405.

Lou H \& Gagel RF 1999 Mechanism of tissue-specific alternative RNA processing of the calcitonin CGRP gene. Frontiers of Hormone Research 25 18-33.

Mangin M, Ikeda K, Dreyer BE, Milstone L \& Broadus AE 1988 Two distinct tumor-derived, parathyroid hormone-like peptides result from alternative ribonucleic acid splicing. Molecular Endocrinology 2 1049-1055.

Marino MT, Budayer AA, Marsden JS \& Strewler GJ 1993 Hypercalcaemia and elevated levels of parathyroid hormone-related protein in cutaneous squamous/basal cell carcinoma. Fournal of Internal Medicine 233 205-207.

Merryman JI, Rosol TJ, Werkmeister JR, McCauley LK, Suter MM \& Capen CG 1993 Regulation of parathyroid hormone-related protein production in a squamous cell carcinoma cell line (SCG 2/88). Laboratory Investigation 69 347-354.

Merryman JI, DeWille JW, Werkmeister JR, Capen CC \& Rosol TJ 1994 Effects of transforming growth factor-beta on parathyroid hormone-related protein production and ribonucleic acid expression by a squamous carcinoma cell line in vitro. Endocrinology $1342424-2430$.

Mitchell P \& Tollervey D 2000 mRNA stability in eukaryotes. Current Opinion in Genetics and Development 10 193-198.

Nishigaki Y, Ohsaki Y, Toyoshima E \& Kikuchi K 1999 Increased serum and urinary levels of a parathyroid hormone-related protein $\mathrm{COOH}$ terminus in non-small cell lung cancer patients. Clinical Cancer Research 5 1473-1481.

Philbrick WM, Wysolmerski JJ, Galbraith S, Holt E, Orloff JJ, Yang KH, Vasavada RC, Weir EC, Broadus AE \& Stewart AF 1996 Defining the roles of parathyroid hormone-related protein in normal physiology. Physiological Reviews 76 127-173.

Rankin W, Grill V \& Martin TJ 1997 Parathyroid hormone-related protein and hypercalcemia. Cancer 80 1564-1571.
Richard V, Luchin A, Brena RM, Lima DF, Plass C \& Rosol TJ 2003 Quantitative evaluation of alternative promoter usage and 3' splice variants for parathyroid hormone-related protein by real-time reverse transcription-PCR assay. Clinical Chemistry 49 1398-1402.

Rosol TJ \& Capen CG 1992 Biology of disease: mechanisms of cancer-induced hypercalcemia. Laboratory Investigation 67 680-702.

Sellers RS, Schuller DE, Sharma PK, Tannehill-Gregg SH, Capen CC \& Rosol TJ 2000 Head and neck squamous cell carcinoma: measurement of plasma parathyroid hormone-related protein and serum and urine calcium concentrations. Otolaryngology - Head and Neck Surgery 123 558-562.

Sellers RS, Capen CG \& Rosol TJ 2002 Messenger RNA stability of parathyroid hormone-related protein regulated by transforming growth factor- $\beta 1$. Molecular and Cellular Endocrinology 188 37-46.

Smith CW \& Valcarcel J 2000 Alternative pre-mRNA splicing: the logic of combinatorial control. Trends in Biochemical Sciences $\mathbf{2 5}$ 381-388.

Southby J, O'Keefe LM, Martin TJ \& Gillespie MT 1995 Alternative promoter usage and mRNA splicing pathways for parathyroid hormone-related protein in normal tissues and tumours. British Fournal of Cancer 72 702-707.

Southby J, Murphy LM, Martin TJ \& Gillespie MT 1996 Cell-specific and regulator-induced promoter usage and messenger ribonucleic acid splicing for parathyroid hormone-related protein. Endocrinology 137 1349-1357.

Suter MM, Pantano DM, Flanders JA, Agustin-Voss HG, Dougherty EP \& Varvayanis M 1991 Comparison of growth and differentiation of normal and neoplastic canine keratinocyte cultures. Veterinary Pathology 28 131-138.

Takai E, Yano T, Iguchi H, Fukuyama Y, Yokoyama H, Asoh H \& Ichinose Y 1996 Tumor-induced hypercalcemia and parathyroid hormone-related protein in lung carcinoma. Cancer 78 1384-1387.

Tannehill-Gregg S, Kergosien E \& Rosol TJ 2001 Feline head and neck squamous cell carcinoma cell line: characterization, production of parathyroid hormone-related protein, and regulation by transforming growth factor- $\beta$. In Vitro Cellular $\mathcal{E}^{\circ}$ Developmental Biology. Animal 37 676-683.

Wakefield LM \& Roberts AB 2003 TGF- $\beta$ signaling: positive and negative effects on tumorigenesis. Current Opinion in Genetics $\mathcal{E}^{\circ}$ Development 12 22-29.

Werkmeister JR, Blomme EA, Weckmann MT, Groene A, McCauley LK, Wade AB, O'Rourke J, Capen CC \& Rosol TJ 1998 Effect of transforming growth factor- $\beta 1$ on parathyroid hormone-related protein secretion and mRNA expression by normal human keratinocytes in vitro. Endocrine 8 291-299.

Wilson GM, Sutphen K, Chuang K \& Brewer G 2001 Folding of A+U-rich RNA elements modulates AUFl binding. Potential roles in regulation of mRNA turnover. Fournal of Biological Chemistry 276 8695-8704.

Wysolmerski JJ \& Stewart AF 1998 The physiology of parathyroid hormone-related protein: an emerging role as a developmental factor. Annual Review of Physiology 60 431-460.

Received 20 January 2004 Accepted 26 April 2004 